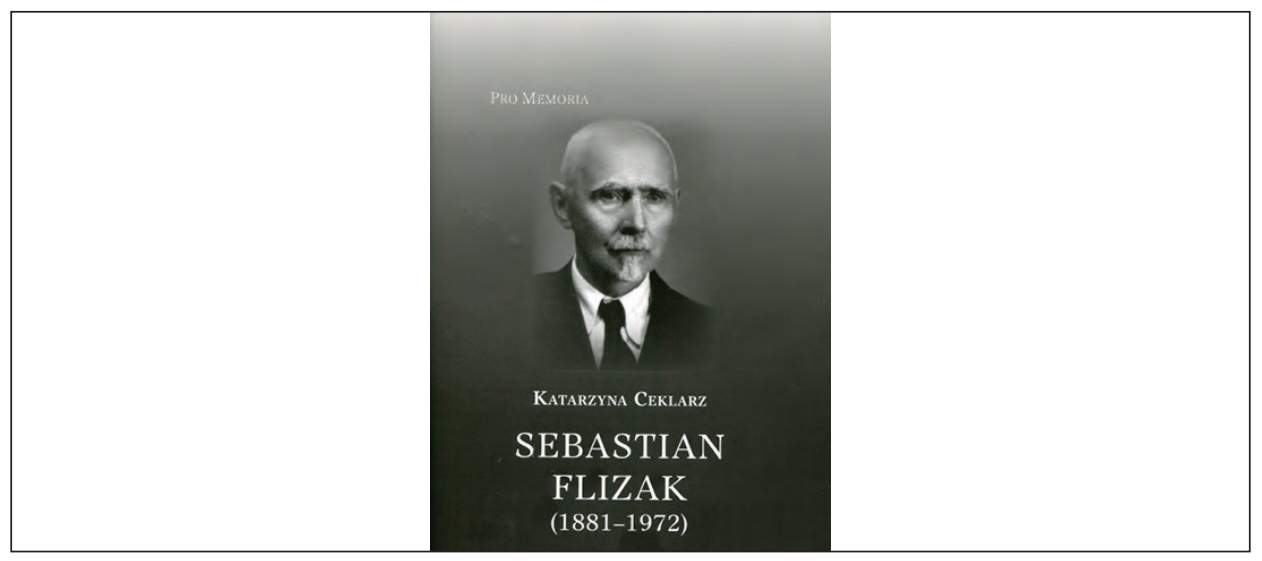

\title{
Separatysta gorczański wobec „podhalanizacji”. 0 życiu i dorobku Sebastiana Flizaka
}

https://doi.org/10.19195/2084-4107.13.31

[rec.:] Katarzyna Ceklarz, Sebastian Flizak (1881-1972). Ludoznawca i etnograf na tle swojej epoki, Centralny Ośrodek Turystyki Górskiej PTTK, Kraków 2019, ss. 402.

The Gorce Mountains separatist in the face of "podhalanisation". About the life and works of Sebastian Flizak

Słowa-klucze: Sebastian Flizak, Katarzyna Ceklarz, Zagórze, Gorce, etnografia

Keywords: Sebastian Flizak, Katarzyna Ceklarz, Zagórze, Gorce, ethnography

Kultura i historia górali zagórzańskich to tematy wciąż pozostające w cieniu zagadnień dotyczących szeroko pojętego regionalizmu podhalańskiego. Gorce postrzegane jako osobny region, a szczególnie ich północne tereny, są przez wielu znawców góralszczyzny pomijane bądź traktowane jako część zunifikowanego Podtatrza. Podobną perspektywę przez wieki przyjmowali także artyści, literaci i społecznicy. Obecnie, w dobie nowego regionalizmu, który duży nacisk kładzie na wyjątkowość i autentyzm najmniejszych nawet subkultur, istotne stają się badania zgłębiające całościową wiedzę o mikroregionach. Zajmujące się tym nauki, od etnografii przez kulturoznawstwo po językoznawstwo, dostrzegają zagrożenie zatarcia się różnic międzyregionalnych, wynikające między innymi z globalizacji. 
W odpowiedzi pojawiają się coraz liczniejsze projekty badawcze mające na celu przywrócenie pamięci o dziedzictwie kulturowym regionów peryferyjnych.

Katarzyna Ceklarz, etnolożka i znawczyni historii, kultury i tradycji Podtatrza, w swym dotychczasowym dorobku ma między innymi prace dotyczące magii i wierzeń ${ }^{1}$ czy opracowania wielu zagadnień kulturowych (medycyna i sztuka ludowa, tradycje pasterskie) $)^{2}$. W pracy badawczej często zajmuje się bliskim jej terenem Zagórza, graniczącego od południa $z$ Podhalem. $Z$ jednej strony sama zgłębia wiedzę o Zagórzu i Zagórzanach, z drugiej bada historię ważnego znawcy tego regionu Sebastiana Flizaka uznanego etnografa, urodzonego w 1881 roku w Podobinie. Z pochodzenia był on góralem zagórzańskim. Troska o zachowanie dziedzictwa kulturowego jego małej ojczyzny, przekładająca się na aktywność badawczą, pisarską i społeczną, wypełniła większą część jego życia. To jemu poświęcona jest pasjonująca, bogato udokumentowana i dobrze napisana monografia autorstwa Katarzyny Ceklarz Sebastian Flizak (1881-1972). Ludoznawca i etnograf na tle swojej epoki, wydana przez Oficynę Wydawniczą Wierchy i COTG PTTK.

Podstawą książki była rozprawa doktorska, nad którą badaczka pracowała do 2017 roku pod kierunkiem prof. dr. hab. Jana Święcha z Uniwersytetu Jagiellońskiego. W dużej mierze monografia została opracowana na podstawie trudno dostępnych i nieznanych wcześniej materiałów archiwalnych. Społeczna aktywność Flizaka związana z regionem Gorce została w niej przedstawiona obiektywnie na tle szerokiego kontekstu historycznego. Aby umożliwić czytelnikowi zrozumienie specyfiki dziewiętnastowiecznej wsi gorczańskiej, formującej osobowość Flizaka, autorka prezentuje historyczne uwarunkowania mające wpływ na kształtowanie się odrębnej tożsamości tego regionu, zwracając szczególną uwagę na zmiany w prawach własności ziemi, determinujące sytuację ekonomiczną Zagórza i jego mieszkańców. Dokonuje także analizy lokalnej mentalności.

W biografii omówione zostały wszystkie etapy życia Flizaka z wyszczególnieniem okresu jego edukacji i kariery nauczycielskiej, następnie udziału w I wojnie światowej i doświadczenia syberyjskiej niewoli oraz przypadającego na lata międzywojenne rozwoju zainteresowania ludoznawstwem i powrotu do Zagórza, gdzie Flizak zajął się pracą etnograficzną.

Podstawowym źródłem służącym autorce do opracowania dziejów etnografa był maszynopis pamiętnika Spod Gorców w świat i z powrotem, spisanego przez etnografa w latach 1953-1956 ${ }^{3}$. Zgromadzone w nim informacje autorka weryfikuje i uzupełnia, korzystając z innych odnalezionych archiwaliów. Dzięki temu

${ }^{1}$ K. Ceklarz, U. Janicka-Krzywda, Czary góralskie. Magia Podtatrza i Beskidów Zachodnich, Zakopane 2014.

${ }^{2}$ Ceklarz opracowała rozdziały: Rzemiosto, przemyst i sztuka ludowa; Medycyna ludowa; Tradycje pasterskie; Muzealnictwo [w:] Kultura ludowa Górali Zagórzańskich, red. U. Janicka-Krzywda, Kraków 2013, s. 97-134, 183-232, 279-310, 387-408.

3 S. Flizak, Spod Gorców w świat i z powrotem. Pamiętnik z lat 1881-1956, mps, Zakład Narodowy im. Ossolińskich, sygn. 15392/II, s. 825. 
monografia Ceklarz jest jedyną wydaną do tej pory rzetelną biografią Flizaka. Sama badaczka krytycznie odnosi się do powstałych wcześniej opracowań, wskazuje błędy, nieścisłości i zwraca uwagę na ich powierzchowność. Przedstawiony przez Ceklarz stan badań dotyczących życia i działalności zagórzańskiego etnografa prowadzi do konkluzji, iż opracowana przez nią biografia Sebastian Flizak (1881-1972)... jest odpowiedzią na współczesne regionalne zapotrzebowanie poznawcze i bez wątpienia wypełnia ona istotną lukę w piśmiennictwie humanistycznym.

Barwny życiorys Flizaka pozwolił Ceklarz na stworzenie zajmującej narracji, która w spójny sposób przedstawia rozmaite epizody z życia omawianego badacza, związane z dojmującym przeżyciem pokoleniowym, jakim w jego wypadku były obie wojny światowe. Autorka zarysowuje między innymi losy biednego ucznia w galicyjskim Krakowie i ciekawie naświetla relacje rodzinne i sąsiedzkie panujące w okresie młodości Flizaka w małej gorczańskiej wsi. Chronologiczna prezentacja kolejnych istotnych wydarzeń z życia etnografa w połączeniu ze wskazaniem kontekstu historycznego i społecznego daje czytelnikowi możliwość zrozumienia mechanizmów, które wpływały na jego życiowe decyzje. Sylwetka Flizaka przedstawiona jest $\mathrm{w}$ książce wieloaspektowo, z uwzględnieniem zarówno sfery jego życia prywatnego, jak i kolejnych etapów rozwoju jego kariery naukowej. Oprócz perypetii rodzinnych i zdrowotnych autorka dokładnie omawia dwutorową ścieżkę jego kariery (nauczycielskiej i etnograficznej). Zwraca przy tym uwagę na trudne warunki życia, biedę, a nawet doświadczenie głodu, z jakimi przyszły etnograf musiał się zmagać, aby osiągnąć cele zawodowe. Ceklarz wskazuje także na pewne obszary zainteresowań Flizaka z okresu akademickiego, które można uznać za prekursorskie w aspekcie badań nad problematyką górską, prowadzonych dzisiaj z perspektywy humanistycznej i literaturoznawczej:

Każdy stypendysta rządowy zobowiązany był do napisania rozprawy naukowej, która obok stosownych wpisów w indeksie miała stanowić dowód dobrze wykorzystanego czasu. Flizak zajął się tematyką górską. Przedmiotem jego analitycznej pracy były opisy Alp w utworach wybranych niemieckich poetów ${ }^{4}$.

Ceklarz odwołuje się również do pamiętnika Flizaka, w którym sam etnograf stwierdza:

Wyczytałem mianowicie w pewnym piśmie literackim, że nikt jeszcze nie próbował opracować w historycznym ujęciu poezji, która za przedmiot ma góry. [...] Istnieje bogactwo utworów poetyckich o piękności Alp, o góralach alpejskich, tak że po uporządkowaniu materiału uogólnienia

${ }^{4}$ K. Ceklarz, Sebastian Flizak (1881-1972) - ludoznawca i etnograf na tle swojej epoki, Kraków 2019, s. 110. 
same się narzucą. I postanowiłem napisać studium o Alpach w poezji niemieckiej ${ }^{5}$.

Omawiając relacje Flizaka z wybitnymi przedstawicielami epoki, w której żył i pracował, Ceklarz wielokrotnie podkreśla trudną relację między Flizakiem a Władysławem Orkanem. Autorka stara się wytłumaczyć genezę konfliktu między zagórzańskimi inteligentami. Wywód Ceklarz potwierdza, że poglądy Flizaka i Orkana na góralszczyznę, Podhale, zwłaszcza zaś na odrębność etniczną i kulturową Zagórzan różniły się wyraźnie. Warto dodać, że do dziś ich opozycyjność pozostaje aktualna i uwidocznia się w podziałach ideowych współczesnych naukowców i samych górali. Obecne aktualizacje problematyki dotyczącej regionalizmu podhalańskiego i jego stosunku do mniejszych, stojących w cieniu Podhala kultur góralskich są częścią dyskursu, który ciekawie rozwija i uzupełnia książka Ceklarz.

Inną istotną kwestią podejmowaną przez Flizaka i szeroko komentowaną w książce Ceklarz był spór o granice Podhala, wciąż aktualny i potrzebujący konsensusu. Jasny, purystyczny pogląd etnografa sugeruje, iż granica między Podhalem a Zagórzem przebiega przez Olszówkę i na północ od niej elementy kultury zagórzańskiej nie powinny być identyfikowane z podhalańską. Dla wielu osób, między innymi dla Orkana, koncepcja ta była nie do zaakceptowania i także wśród innych animatorów ruchu regionalnego na Podhalu wzbudzała liczne kontrowersje. Może jednak, w kontekście współczesnego rozwoju świadomości kulturowej odrębności Gorców, warto pójść tropem Flizaka, poznać Zagórze i jego mieszkańców i dostrzec kulturową odrębność tego obszaru. Jak się wydaje, odmienna specyfika położonego w cieniu Tatr subregionu gorczańskiego może okazać się ciekawą alternatywą dla podhalanizmu i wszechobecnej „podhalanizacji” góralszczyzny.

Książka Ceklarz wyraźnie uświadamia, że etnograficzny dorobek Flizaka może być dzisiaj cennym źródłem poznania kulturowych zasobów Zagórza. Autorka, omawiając bogate piśmiennictwo etnografa, słusznie postuluje potrzebę wydania pełnego zbioru jego pism, między innymi rozproszonych artykułów, a także fragmentów nieukończonych książek. Zawierają one bowiem nie tylko wartościowy poznawczo materiał etnograficzny, lecz także komentarze dotyczące współczesnej Flizakowi rzeczywistości, które mogą posłużyć jako dokumenty historyczne.

Przeglądu i zestawienia pism Flizaka autorka dokonuje w drugiej części książki, gdzie uwzględnia zarówno pozycje wydane, jak i te archiwizowane jako manuskrypty i rękopisy. Ceklarz nie tylko podkreśla ważność prezentowanych w nich treści, ale też omawia je, pozwalając czytelnikowi na zorientowanie się w charakterze dorobku etnografa. Dzięki dołączeniu do monografii szczegółowego wykazu jego prac prezentowana tu książka pełni także ważną dla współczesnych czytelników i badaczy funkcję przewodnika bibliograficznego.

\footnotetext{
5 S. Flizak, op. cit., s. 298, cyt. za: K. Ceklarz, op. cit., s. 110.
} 
Biografia Flizaka autorstwa Ceklarz, nie uchybiając zasadom obiektywnej oceny rzeczywistego dorobku bohatera książki, to pewnego rodzaju apoteoza jego dokonań, co jest raczej jej zaletą aniżeli wadą. Lektura tej ważnej i dobrze napisanej książki sprawia, że trudne, przejmujące losy badacza, których zwieńczeniem była intensywna praca na rzecz ,utrwalenia zmieniającego się krajobrazu kulturowego" Gorców nie pozwala myśleć o Flizaku inaczej niż jako o ważnym aktorze regionalnym niezwykle zasłużonym dla utrwalania świadomości regionalnej odrębności Gorców i stanowiącego ich część integralną Zagórza. W podsumowaniu autorka stawia celne pytanie: ,jaki współcześnie byłby poziom wiedzy na temat Górali Zagórzańskich, gdyby nie spuścizna Flizaka?”?.

Maria Kościelniak

ORCID: 0000-0003-4438-2533

Uniwersytet Wrocławski mariakoscielniak@op.pl

${ }^{6}$ K. Ceklarz, op. cit., s. 296.

7 Ibidem, s. 295. 